\section{Tinjauan Pustaka}

\section{PENGGUNAAN TELEMEDICINE PADA MASA PANDEMI COVID-19: PROSPEK DAN TANTANGAN}

\author{
Muhammad Luthfi Adnan, ${ }^{1}$ Miranti Dewi \\ Pramaningtyas, ${ }^{2}$ \\ 'Program Studi Pendidikan Dokter, Fakultas Kedokteran, \\ Universitas Islam Indonesia, Sleman, Indonesia \\ 2Departemen Fisiologi, Fakultas Kedokteran, Universitas \\ Islam Indonesia, Sleman, Indonesia
}

\begin{abstract}
ABSTRAK
Pendahuluan: Pandemi COVID-19 telah menjadi salah satu permasalahan kesehatan global saat ini. Kebijakan physical distancing dan karantina mandiri yang dilakukan untuk memutuskan rantai penularan penyakit menyulitkan interaksi antara dokter dan pasien. Telemedicine merupakan layanan kesehatan jarak jauh menggunakan sarana elektronik untuk mendiagnosis, mengobati, dan mencegah penyakit dan cedera, penelitian dan edukasi, serta pendidikan untuk penyedia layanan kesehatan untuk meningkatkan kesehatan. Tujuan dari tinjauan pustaka ini adalah membahas mengenai penggunaan telemedicine selama pandemi COVID-19 saat ini dan tantangan penggunaanya untuk pemanfaatannya bagi praktek medis di masa depan.

Metode: Pencarian literatur dilakukan dengan menggunakan mesin pencari PubMed, Science Direct dan Google Scholar. Pencarian literatur dilakukan dengan menggunakan kombinasi kata kunci medical practice", "COVID-19 pandemic", "telemedicine", "telehealth", "management" dan "medical practice".

Pembahasan: Pandemi COVID-19 saat ini meningkatkan beban sistem kesehatan. Penggunaan telemedicine dapat menerapkan perawatan medis di rumah tanpa pasien perlu pergi ke rumah sakit. Telemedicine membantu menurunkan risiko penularan COVID-19 dan membantu masyarakat mendapatkan akses kesehatan. Tantangan dari penggunaan telemedicine saat ini terkait sumber daya manusia, infrastruktur serta etik yang mengakibatkan penggunaan telemedicine masih belum dapat dimaksimalkan.

Simpulan: Penggunaan teknologi telemedicine dapat membantu aktivitas dokter dalam interaksi perawatan pasien. Penelitian lebih lanjut diperlukan untuk meningkatkan efektivitas telemedicine untuk praktek dokter yang lebih baik di masa depan.
\end{abstract}

Kata Kunci: COVID-19, pandemi, praktek medis, telemedicine 
e-ISSN: 2721-1924

ISSN: 2302-6391

\title{
TELEMEDICINE USE DURING COVID-19 PANDEMIC : PROSPECTS AND CHALLENGES
}

\begin{abstract}
Background: COVID-19 pandemic has become one of the current global health problems. The physical distancing and self-quarantine policies implemented to break the chain of disease complicate the interaction between doctors and patients. Telemedicine is a remote health service using electronic means for diagnosis, treatment and prevention of disease and injury, research and education, and education of health service providers to improve health. The purpose of this literature review is to discuss the use of telemedicine during the current COVID19 pandemic and the challenges of using it for its use in future medical practice.

Methods: Literature searches were performed using the search engines PubMed, Science Direct and Google Scholar. Literature search using a combination of keywords medical practice", "COVID-19 pandemic", "telemedicine", "telehealth", "management" and "medical practice".

Discussion: The current COVID-19 pandemic is increasing the burden on the health system. The use of telemedicine can implement medical care at home without the patient needing to go to the hospital. Telemedicine helps reduce the risk of contracting COVID-19 and helps people get access to health. The challenges of using telemedicine today are related to human resources, infrastructure and ethics. As a result, the use of telemedicine has not been maximized.

Conclusion: The use of telemedicine technology can help doctors in patient care interactions. Further research is needed to increase the effectiveness of telemedicine for better medical practice in the future.
\end{abstract}

Keywords: COVID-19, medical practice, pandemic, telemedicine

\section{PENDAHULUAN}

Sejak kemunculannya di Wuhan, China pada Desember 2019, infeksi COVID-19 yang disebabkan oleh virus SARS-COV-2 telah menjadi salah satu permasalahan kesehatan global saat ini.[1] Berdasarkan laporan WHO, COVID-19 telah menginfeksi lebih dari 6 juta jiwa dan menyebabkan lebih dari 300 ribu kematian di seluruh dunia. Penyebaran yang cepat dari virus SARS-CoV-2 dapat terjadi melalui kontak penderita dengan orang sehat melalui udara atau droplet. ${ }^{[2]}$ Penyebaran yang cepat menimbulkan dampak merugikan pada setiap segi kehidupan manusia dari lintas sektor sehingga dapat mempersulit keberlangsungan hidup manusia secara normal.[3]

Kebijakan physical distancing dan karantina mandiri yang dilakukan untuk memutuskan rantai penularan penyakit menyulitkan interaksi antara dokter dan pasien. ${ }^{[4]}$ Kondisi pandemi COVID-19 mengakibatkan perubahan yang tidak biasa dalam praktek dokter. ${ }^{[5]}$ Situasi pandemi saat ini membuat para dokter beradaptasi dengan kondisi sekarang, salah satunya dengan menggunakan telemedicine dalam menyediakan layanan kesehatan. Telemedicine didefinisikan sebagai penyampaian layanan kesehatan jarak jauh menggunakan sarana elektronik untuk mendiagnosis, mengobati, mencegah penyakit dan cedera, penelitian dan edukasi, serta pendidikan penyedia layanan kesehatan ${ }^{\left[{ }^{[6]} \text { Penggunaan }\right.}$ telemedicine memiliki manfaat karena efektivitas biaya, meningkatkan outcome kesehatan, dan mendorong kepuasan pasien yang memerlukan perawatan terutama pasien dengan penyakit kronis seperti diabetes mellitus tipe 2 dan kanker. ${ }^{[7,8]}$

Namun, telemedicine masih belum banyak dipelajari karena keterbatasannya 
baik oleh regulator, institusi hingga kompetensi yang diperlukan dalam penggunaannya..$^{[9]}$ Telemedicine juga kurang familiar bagi para dokter yang kurang memahami mengenai pengaruh kegunaannya dalam setiap praktek medis. ${ }^{10]}$ Dalam situasi pandemi saat ini, dokter-dokter akan berusaha menggunakan teknologi ini untuk perawatan pasien rawat jalan dengan mempermudah akses dan kenyamanan perawatan selama krisis COVID-19..11]

Tujuan dari tinjauan pustaka ini adalah membahas mengenai penggunaan telemedicine selama pandemi COVID-19 saat ini dan tantangan penggunaanya untuk pemanfaatannya bagi praktek medis di masa depan.

\section{METODE}

Pencarian literatur dilakukan dengan menggunakan mesin pencari PubMed, Science Direct dan Google Scholar. Pencarian literatur dengan menggunakan kombinasi kata kunci "medical practice", "COVID-19 pandemic", "telemedicine", "telehealth", "management" dan "medical practice". Kriteria inklusi yang digunakan adalah artikel fulltext berbahasa Inggris, literatur berupa randomized controlled trial (RCT), pilot study, clinical trial, observasional study dan review dengan publikasi tidak lebih dari 10 tahun terakhir. Literatur yang ditemukan kemudian melalui proses skrining pada pustaka yang digunakan untuk mencari literatur lainnya yang dapat mendukung penyusunan tinjauan ini.

\section{PEMBAHASAN}

\subsection{Kesulitan Praktek Dokter Selama Krisis COVID-19}

Pandemi COVID-19 menyebabkan krisis global yang berdampak pada beban sistem kesehatan yang belum pernah terjadi. Rumah sakit yang penuh dengan pasien COVID-19 yang memerlukan perawatan dengan cepat berdampak pada kondisi pekerja medis dan kebutuhan alat perlindungan diri (APD). ${ }^{[12]}$ Bagi para dokter, kesulitan dalam praktek mereka untuk melakukan tindakan medis dapat meliputi operasional, teknologi dan pengetahuan. Krisis COVID-19 saat ini mendorong para dokter untuk mengoperasikan teknologi-teknologi yang kurang dipahami penggunaannya maupun manfaatnya karena kurang familiar pada kondisi saat ini sehingga memaksa para dokter bertindak secara inovatif. ${ }^{[13]}$

Tindakan perawatan pasien COVID19 yang berjumlah banyak menyebabkan para petugas medis mengalami tekanan fisik maupun emosional untuk menghadapi penyakit menular baru yang belum banyak dipelajari mengenai penanganan terbaik terhadap penyakit. ${ }^{[14]}$ Karena jumlah pasien yang perlu perawatan intensif dan sifat penularannya yang masif, krisis ini berdampak juga pada pasien penyakit kronis yang memerlukan perawatan di rumah sakit secara berkala. ${ }^{[15]}$ Banyaknya petugas kesehatan yang diperlukan untuk menangani pasien COVID-19 mengakibatkan pasien penyakit kronis tidak dapat datang ke rumah sakit untuk mendapatkan perawatan yang dibutuhkan. ${ }^{[16]}$ Kondisi ini kemudian memaksa pasien untuk berkonsultasi dengan dokter mereka mengenai kondisi kesehatan tanpa bertatap muka sebagai bagian dari jadwal kontrol pasien, kecuali pada kondisi gawat darurat yang memerlukan tindakan medis seperti bedah. ${ }^{[17]}$

Selama masa pandemi COVID-19 saat ini, pasien dengan penyakit kronis mendapatkan perawatan yang dilakukan di rumah mereka sesuai dengan pedoman dan arahan dari dokter mereka dan dokter cukup memantau perkembangan pasien tanpa perlu melakukan kunjungan ke rumah pasien. ${ }^{[18,19]}$ Pasien dengan penyakit kronis dapat menjadi faktor komorbid yang dapat memperbesar risiko perburukan infeksi COVID-19, sehingga upaya untuk mengurangi penularan dari pasien COVID-19 yang banyak dirawat di rumah sakit perlu dilakukan demi keselamatan nyawa pasien. ${ }^{[19,20]}$ Salah satu penggunaan teknologi dalam praktek kedokteran berupa telemedicine yang dapat menjadi salah satu alternatif dalam praktek kedokteran. 


\subsection{Potensi Penggunaan Telemedicine Selama Pandemi COVID-19}

Penggunaan telemedicine merupakan salah satu terobosan teknologi di bidang kedokteran untuk meningkatkan kualitas layanan kesehatan. ${ }^{[22]}$ Telemedicine dapat dimanfaatkan untuk mengkomunikasikan kebutuhan pasien mengenai konsultasi atas kondisi dirinya kepada dokter pada kondisi dimana pasien tidak dapat mengakses fasilitas kesehatan. Penggunaan telemedicine dalam situasi pandemi dapat meningkatkan penyelidikan epidemiologis, kontrol penyakit, dan manajemen kasus baik pada pasien asimptomatik maupun simptomatik. ${ }^{[23]}$ Melalui penggunaan telemedicine, pasien dengan gejala penyakit yang ringan dapat memperoleh perawatan suportif yang dibutuhkan tanpa perlu berinteraksi dengan pasien lainnya yang berpotensi untuk memperburuk kondisi.[24]

Penggunaan telemedicine dapat menerapkan konsep "hospitality at home" yaitu perawatan medis di rumah, dimana perawatan di rumah dalam beberapa kondisi lebih baik dibandingkan perawatan di rumah sakit demi menghindari infeksi nosokomial dan biaya perawatan medis. [25] Dalam kondisi pandemi COVID-19, telemedicine dapat bermanfaat bagi pasien untuk tidak perlu keluar dari rumah sehingga tingkat kehadiran di ruang tunggu rumah sakit menurun, mengurangi pasien suspek, dan memungkinakn tindak lanjut pasien dengan gejala ringan. Telemedicine memungkinkan dokter layanan primer dan rumah sakit untuk mengalihkan konsultasi tatap muka dengan pasien yang telah dijanjikan dengan teleconsultation bila memungkinkan. ${ }^{[26]} \quad$ Penggunaan telemedicine yang telah diaplikasikan di beberapa negara seperti di Italia dan Prancis memungkinkan pasien untuk mengurangi kunjungan ke rumah sakit dan menurunkan beban sistem kesehatan yang menumpuk akibat perawatan di rumah sakit.[26,27]

Pada kondisi pandemi COVID-19, telemedicine membantu perawatan pasien kronis seperti pasien dengan imunokompromi, kanker, diabetes mellitus dan hipertensi. ${ }^{[28]}$ Penggunaan telemedicine dalam perawatan penyakit kronis memudahkan pengontrolan pengobatan pasien sehingga bermanfaat pada penurunan jumah kunjungan ke rumah sakit dan kedatangan ke unit gawat darurat.[29] Telemedicine dapat mendukung self-management pasien mulai pengaturan dan peran medikasi, modifikasi gaya hidup serta pengaturan emosional pasien secara efektif sehingga meningkatkan kualitas outcome pasien. ${ }^{[30]}$ Melalui penggunaan telemedicine tersebut, pasien dengan penyakit kronis dapat terhindari dari infeksi COVID-19 dan berisiko meningkatkan risiko kematian pasien. ${ }^{[31]}$

Penggunaan telemedicine dapat membantu masyarakat umum untuk mengakses layanan kesehatan. ${ }^{[32]}$ Pasien dapat melakukan konsultasi dengan dokter terkait penyakit yang dialaminya melalui telemedicine tanpa perlu ke rumah sakit, sehingga waktu perjalanan pasien ke layanan kesehatan.[33] Efektivitas telemedicine juga berdampak pada pembiayaan kesehatan yang diperlukan baik dalam persoalan transportasi untuk kunjungan pasien, praktek home visit oleh dokter maupun rawat inap di rumah sakit yang tidak direncanakan. ${ }^{[34]}$ Telemedicine dapat membantu mengatasi persoalan praktek medis dalam skala wilayah yang luas, dimana jarak antara pasien ke layanan kesehatan berpengaruh terhadap biaya layanan kesehatan dan outcome penyakit pasien.[35] Dampaknya, penggunaan telemedicine akan meningkatkan kepuasan pasien untuk mengakses layanan kesehatan dan meningkatkan kondisi kesehatan pasien. ${ }^{[36]}$

\subsection{Tantangan Penggunaan}

Telemedicine dalam Praktek Medis

Meski memiliki potensi untuk meningkatkan kualitas praktek medis selama pandemi, penggunaan telemedicine memiliki beberapa tantangan yaitu terkait sumber daya manusia, infrastruktur dan peraturan etik.[37] Penggunaan telemedicine saat ini masih kurang mendapatkan perhatian oleh para dokter dan pembuat kebijakan kesehatan untuk mengintegrasikan penggunaan telemedicine pada sistem kesehatan nasional. ${ }^{[38]}$ Selama masa pandemi COVID-19 saat ini, penggunaan 
telemedicine oleh para dokter masih terbatas karena keharusan dokter untuk mempelajarai metode konsultasi yang baru dan kompleks. ${ }^{[39]}$ Selain itu, faktor pembuat kebijakan kesehatan mengenai penggunaan telemedicine bergantung pada kondisi geografis dari penerapan teknologi tersebut yang membatasi penggunaan telemedicine di daerah perkotaan karena kemudahan akses ke fasilitas layanan kesehatan dibandingkan di daerah terpencil. Beberapa kebijakan telemedicine yang ada mayoritas menggunakan telemedicine di daerah pedesaan dan daerah terpencil untuk mempermudah masyarakat pedesaan melakukan konsultasi pada dokter tanpa perlu menempuh jarak yang jauh. [40] Dalam kondisi COVID-19, telemedicine diperlukan di populasi padat yang memiliki risiko penularan yang tinggi, seperti di daerah perkotaan. Oleh karena itu, promosi terkait penggunaan telemedicine dapat menjadi prioritas dalam kondisi pandemi untuk meminimalisirkan risiko penularan melalui kontak antar orang. ${ }^{[39]}$

Pengadaan fasilitas telemedicine memerlukan infrastruktur yang dapat menunjang aplikasi penggunaan telemedicine. Infrastruktur dasar seperti listrik, kebutuhan perangkat keras, peralatan komunikasi, dan aplikasi perangkat lunak untuk mendukung kegiatan telemedicine menjadi tantangan utama di negara-negara berkembang. ${ }^{[41]}$ Selain itu, tantangan finansial dari penggunaan telemedicine dalam tindakan medis dikarenakan dari return of investation (ROI) yang tidak jelas akibat ukuran pendapatan yang kabur dan penggantian asuransi yang menyulitkan. ${ }^{[42]}$ Tantangan finansial yang berhubungan dengan pengadaan infrastruktur menjadi penghalang dari pengembangan teknologi yang diperlukan yang membatasi penerapan telemedicine dalam praktek medis. ${ }^{[43]}$

Salah satu tantangan dalam mempromosikan telemedicine adalah tingkat penerimaan teknologi tersebut oleh para dokter yang rendah karena terbatasnya pengetahuan para dokter mengenai telemedicine. ${ }^{[44]}$ Banyak para dokter yang tidak menggunanakan telemedicine dalam prakteknya di rumah sakit karena rendahnya pengetahuan baik mengenai aplikasi, layanan, dan manfaatnya yang dikarenakan perlu waktu untuk beradaptasi mengenai penggunaan telemedicine. ${ }^{[45]}$ Rendahnya penggunaan teknologi telemedicine juga semakin sulit karena belum terintegrasinya telemedicine pada sistem kesehatan nasional. Yang diakibatkan oleh belum ada lembaga yang menaungi penggunaan telemedicine dalam praktek kedokteran baik di rumah sakit atau mandiri.[46]

Selain itu, permasalahan etis mengenai rekam medis menjadi permasalahan para dokter mengenai aksesibilitas dalam penggunaan telemedicine dalam konsultasi dokterpasien. ${ }^{[4,47]}$ Privasi data dan rekam medis menjadi perhatian mengenai permasalahan penggunaan telemedicine dalam setiap tindakan praktek dokter. Kondisi ini disebabkan masih kurangnya regulasi dalam tindakan praktek medis dengan telemedicine. Permasalahan dalam aspek etis terkait informasi pasien untuk keperluan tindakan pengobatan, yang mana aspek tersebut dapat menghabiskan biaya tinggi dalam penyelesaian permasalahan tersebut. ${ }^{[48]}$ Untuk menghadapi permasalahan etis tersebut, dokter perlu menjelaskan kepada pasien mengenai keterbatasan dari tindakan mereka dengan penggunaan telemedicine, sehingga pasien dapat menentukan pilihan untuk menyetujui tindakan dengan menggunakan telemedicine atau menolak. Penggunaan telemedicine oleh dokter juga memerlukan protokol dan regulasi yang jelas untuk meyakinkan pasien mengenai kerahasiaan data dan informasi pasien. ${ }^{49]}$

\section{KESIMPULAN}

Pandemi COVID-19 telah memengaruhi aktivitas dokter dalam interaksi perawatan pasien. Tingginya tingkat penularan COVID-19 akan berdampak buruk pada kondisi kesehatan pasien dengan penyakit kronis sehingga dapat mengancam nyawa pasien., Penggunaan teknologi telemedicine dapat digunakan oleh dokter untuk berinteraksi dengan pasien terkait perawatan pasien 
untuk mengontrol terapi pasien tanpa pasien datang ke rumah sakit untuk bertatap muka dengan dokter. Penggunaan telemedicine dapat mengurangi penularan pada pasien berisiko serta meningkatkan akses layanan kesehatan bagi masyarakat umum. Telemedicine memiliki banyak manfaat untuk memudahkan praktek dokter dan meningkatkan kualitas layanan kesehatan pasien.. Tantangan terkait pemanfaatan teknologi telemedicine antara lain dari sumber daya manusia yang minim terkait penggunaannya di antara dokter, infrastruktur, dan aspek etis yang mengakibatkan penggunaannya banyak mengalami hambatan dalam praktek penggunaan telemedicine di lapangan. Studi lebih lanjut diperlukan untuk mempelajari lebih lanjut manfaat dari telemedicine untuk praktek dokter yang lebih baik sehingga penggunaan telemedicine dapat menjadi terobosan teknologi kesehatan demi kemajuan kedokteran di masa depan.

\section{DAFTAR PUSTAKA}

1. Lu R, Zhao X, Li J, Niu P, Yang B, Wu $\mathrm{H}$, Wang $\mathrm{W}$, Song $\mathrm{H}$, Huang $\mathrm{B}$, Zhu $\mathrm{N}$, Bi Y, Ma X, Zhan F, Wang L, Hu T, Zhou H, Hu Z, Zhou W, Zhao L, Chen J, Meng Y, Wang J, Lin Y, Yuan J, Xie Z, Ma J, Liu WJ, Wang D, Xu W, Holmes EC, Gao GF, Wu G, Chen W, Shi W, Tan W. Genomic characterisation and epidemiology of 2019 novel coronavirus: implications for virus origins and receptor binding. Lancet 2020;395(10224):565-74. 8

2. Raoult D, Zumla A, Locatelli F, Ippolito G, Kroemer G. Coronavirus infections: Epidemiological, clinical and immunological features and hypotheses. Cell Stress [Internet]. 2020;4(4):66-75.

3. Nicola M, Alsafi Z, Sohrabi C, Kerwan A, Al-Jabir A, losifidis C, Agha M, Agha R. The Socio-Economic Implications of the Coronavirus and COVID-19 Pandemic: A Review. Int J Surg. 2020;

4. Scott BK, Hravnak M, Pamplin JC.
Clinical Distancing and Mitigation of Coronavirus Disease 2019. Crit Care Explor. 2020;2(4):e0117.

5. Verhoeven V, Tsakitzidis G, Philips H, Van Royen P. Impact of the COVID19 pandemic on the core functions of primary care: Will the cure be worse than the disease? A qualitative interview study in Flemish GPs. BMJ Open. 2020;10(6).

6. Serper M, Volk ML. Current and Future Applications of Telemedicine to Optimize the Delivery of Care in Chronic Liver Disease. Clin Gastroenterol Hepatol. 2018;16(2):157-161.

7. Elkaddoum R, Haddad FG, Eid R, Kourie HR. Telemedicine for cancer patients during COVID-19 pandemic: between threats and opportunities. Futur Oncol. 2020;10-2.

8. Ghosh A, Gupta R, Misra A. Telemedicine for Diabetes Care in India during COVID19 Pandemic and National Lockdown Period: Guidelines for Physicians. Diabetes Metab Syndr Clin Res Rev. 2020;

9. Contreras $\mathrm{CM}$, Metzger GA, Beane JD, Dedhia PH, Ejaz A, Pawlik TM. Telemedicine: Patient-Provider Clinical Engagement During the COVID-19 Pandemic and Beyond. J Gastrointest Surg. 2020;

10. Maleki M, Mousavi SM, Khosravizadeh O, Heidari $M$, Raadabadi M, Jahanpour M. Factors affecting use of telemedicine and telesurgery in cancer care (TTCC) among specialist physicians. Asian Pacific J Cancer Prev. 2018;19(11):3123-9.

11. Mann DM, Chen J, Chunara R, Testa PA, Nov O. COVID-19 transforms health care through telemedicine: evidence from the field. J Am Med Inform Assoc. 2020;

12. Ventura C, Gibson C, Collier GD. Emergency Medical Services resource capacity and competency amid COVID-19 in the United States: preliminary findings from a national survey. Heliyon [Internet]. 2020;6(5):e03900.

13. Fong ZV, Qadan M, McKinney R, 
Griggs CL, Shah PC, Buyske J, Sachdeva AK, Callery MP, Altieri MS. Practical Implications of Novel Coronavirus COVID-19 on Hospital Operations, Board Certification, and Medical Education in Surgery in the USA. J Gastrointest Surg. 2020;

14. Liu Q, Luo D, Haase JE, Guo Q, Wang $X Q$, Liu S, Xia L, Liu Z, Yang J, Yang $B X$. The experiences of health-care providers during the COVID-19 crisis in China: a qualitative study. Lancet Glob Heal. 2020;(January).

15. Kretchy IA, Asiedu-Danso M, Kretchy $\mathrm{J}$-P. Medication management and adherence during the COVID-19 pandemic: Perspectives and experiences from LMICs. Res Soc Adm Pharm. 2020;

16. Kang C, Yang S, Yuan J, Xu L, Zhao $X$, Yang J. Patients with chronic illness urgently need integrated physical and psychological care during the COVID19 outbreak. Asian J Psychiatr. 2020;51(January).

17. Eccleston C, Blyth FM, Dear BF, Fisher EA, Keefe FJ, Lynch ME, Palermo TM, Reid MC, Williams AC d. C. Managing patients with chronic pain during the COVID-19 outbreak: considerations for the rapid introduction of remotely supported (eHealth) pain management services. Pain. 2020;161(5):889-93.

18. Bendelin $N$, Björkdahl $P$, Risell $M$, Nelson KZ, Gerdle B, Andersson G, Buhrman M. Patients' experiences of internet-based Acceptance and commitment therapy for chronic pain: A qualitative study. BMC Musculoskelet Disord. 2020;21(1):112.

19. Hollander JE, Carr BG. Virtually Perfect? Telemedicine for Covid-19. N Engl J Med [Internet]. 2020.

20. Zhang J, Wang X, Jia X, Li J, Chen G, Wei J, Gong Z, Zhou C, Yu H, Yu M, Lei $H$, Cheng $F$, Zhang $B, X u Y$, Wang G, Dong W. Risk factors for disease severity, unimprovement, and mortality of COVID-19 patients in Wuhan, China. Clin Microbiol Infect. 2020;

21. Richez C, Lazaro E, Lemoine $M$,
Truchetet ME, Schaeverbeke T. Implications of COVID-19 for the management of patients with inflammatory rheumatic diseases. Vol. 87, Joint Bone Spine. 2020. p. 187-9.

22. Baker J, Stanley A. Telemedicine Technology: a Review of Services, Equipment, and Other Aspects. Curr Allergy Asthma Rep. 2018;18(11).

23. Ohannessian R. Telemedicine: Potential applications in epidemic situations. Eur Res Telemed. 2015;4(3):95-8.

24. Portnoy J, Waller $M$, Elliott $T$. Telemedicine in the Era of COVID-19. $J$ Allergy Clin Immunol Pract. 2020;8(5):1489-91.

25. Woolliscroft JO. Innovation in Response to the COVID-19 Pandemic Crisis. Acad Med. 2020;XX(X):1-3.

26. Ohannessian R, Duong TA, Odone A. Global Telemedicine Implementation and Integration Within Health Systems to Fight the COVID-19 Pandemic: A Call to Action. JMIR Public Heal Surveill. 2020;6(2):e18810.

27. Negrini $S$, Kiekens $C$, Bernetti $A$, Capecci M, Ceravolo MG, Lavezzi S, Zampolini M, Boldrini P. Telemedicine from research to practice during the pandemic. "Instant paper from the field" on rehabilitation answers to the Covid-19 emergency. Eur J Phys Rehabil Med. 2020;

28. Silva CA, Queiroz LB, Fonseca $C$ de B, Silva LEV da, Lourenço B, Marques HHS. Spotlight for healthy adolescents and adolescents with preexisting chronic diseases during the COVID-19 pandemic. Clinics (Sao Paulo). 2020;75:e1931.

29. Orozco-Beltran D, Sánchez-Molla $M$, Sanchez JJ, Mira JJ. Telemedicine in primary care for patients with Chronic conditions: The valcrònic quasiexperimental study. J Med Internet Res. 2017;19(12):1-12.

30. Hanlon $P$, Daines L, Campbell C, Mckinstry B, Weller D, Pinnock $\mathrm{H}$. Telehealth interventions to support self-management of long-term conditions: A systematic metareview of diabetes, heart failure, asthma, chronic obstructive pulmonary 
disease, and cancer. J Med Internet Res. 2017;19(5).

31. Guan WJ, Liang $W H$, Zhao $Y$, Liang HR, Chen ZS, Li YM, Liu XQ, Chen RC, Tang CL, Wang T, Ou CQ, Li L, Chen PY, Sang L, Wang W, Li JF, Li CC, Ou LM, Cheng B, Xiong S, Ni ZY, Xiang J, Hu Y, Liu L, Shan H, Lei CL, Peng YX, Wei L, Liu Y, Hu YH, Peng $P$, Wang JM, Liu JY, Chen Z, Li G, Zheng ZJ, Qiu SQ, Luo J, Ye CJ, Zhu SY, Cheng LL, Ye F, Li SY, Zheng JP, Zhang NF, Zhong NS, He JX. Comorbidity and its impact on 1590 patients with COVID-19 in China: a nationwide analysis. Eur Respir J. 2020;(March 2020).

32. O'Gorman LD, Hogenbirk JC, Warry W. Clinical telemedicine utilization in Ontario over the Ontario telemedicine network. Telemed e-Health. 2016;22(6):473-9.

33. Portnoy JM, Pandya A, Waller M, Elliott $\mathrm{T}$. Telemedicine and emerging technologies for health care in allergy/immunology. J Allergy Clin Immunol [Internet]. 2020;145(2):44554.

34. Correard F, Montaleytang M, Costa M, Astolfi $\mathrm{M}$, Baumstarck $\mathrm{K}$, Loubière $\mathrm{S}$, Amichi K, Auquier P, Verger P, Villani $P$, Honore $S$, Daumas A. Impact of medication review via tele-expertise on unplanned hospitalizations at 3 months of nursing homes patients (TEM-EHPAD): Study protocol for a randomized controlled trial. BMC Geriatr. 2020;20(1):1-11.

35. Agarwal $P$, Kithulegoda N, Umpierre R, Pawlovich J, Pfeil JN, D'Avila OP, Goncalves M, Harzheim E, Ponka D. Telemedicine in the driver's seat: new role for primary care access in Brazil and Canada. Can Fam Physician. 2020;66:104-11.

36. Waller M, Stotler C. Telemedicine: a Primer. Curr Allergy Asthma Rep. 2018;18(10):1-9.

37. Tedeschi C. Social, Legal and Ethical Challenges in the Development and Implementation of Disaster Telemedicine. Disaster Med Public Health Prep. 2020;1-8.

38. Omboni S. Telemedicine During The
COVID-19 in Italy: A Missed Opportunity? Telemed e-Health. 2020;00(00):19-21.

39. Smith AC, Thomas E, Snoswell CL, Haydon H, Mehrotra A, Clemensen J, Caffery LJ. Telehealth for global emergencies: Implications for coronavirus disease 2019 (COVID19). J Telemed Telecare. 2020;2019.

40. Kichloo A, Albosta M, Dettloff K, Wani F, El-Amir Z, Singh J, Aljadah M, Chakinala RC, Kanugula AK, Solanki $\mathrm{S}$, Chugh S. Telemedicine, the current COVID-19 pandemic and the future: a narrative review and perspectives moving forward in the USA. Fam Med community Heal. 2020;8(3):1-9.

41. Combi C, Pozzani G, Pozzi G. Telemedicine for developing countries: A survey and some design issues. Appl Clin Inform. 2016;7(4):1025-50.

42. Iribarren SJ, Cato K, Falzon L, Stone $\mathrm{PW}$. What is the economic evidence for mHealth? A systematic review of economic evaluations of mHealth solutions. PLoS One. 2017;12(2):120.

43. Kim T, Zuckerman JE. Realizing the potential of telemedicine in global health. J Glob Health. 2019;9(2).

44. Ayatollahi H, Fatemeh S, Mostafa L. Clinicians ' Knowledge and Perception of Telemedicine Technology. Perspect Heal Inf Manag [Internet]. 2015;12(1c):1-6.

45. El-Mahalli AA, El-Khafif SH, AlQahtani MF. Successes and challenges in the implementation and application of telemedicine in the eastern province of Saudi Arabia. Perspect Heal Inf Manag Assoc. 2012;9:1-27.

46. LeRouge $\mathrm{C}$, Garfield MJ. Crossing the telemedicine chasm: Have the U.S. barriers to widespread adoption of telemedicine been significantly reduced? Int J Environ Res Public Health. 2013;10(12):6472-84.

47. Rho MJ, Choi I young, Lee J. Predictive factors of telemedicine service acceptance and behavioral intention of physicians. Int $\mathrm{J}$ Med Inform [Internet]. 2014;83(8):559-71. 
48. Nittari $G$, Khuman $R$, Baldoni $S$, Pallotta G, Battineni G, Sirignano A, Amenta F, Ricci G. Telemedicine Practice: Review of the Current Ethical and Legal Challenges. Telemed e-Health. 2020;1-11.
49. Chaet D, Clearfield R, Sabin JE, Skimming $K$. Ethical practice in Telehealth and Telemedicine. J Gen Intern Med [Internet]. 2017;32(10):1136-40. 